\title{
Cabbage : a new host of Sclerotinia sclerotiorum for Pakistan
}

M. Siddique MIRZA \& Yasmin AHMAD

National Agricultural Research Centre PARC, Islamabad, Pakistan.

Sclerotinia rot of cabbage was detected at National Agricultural Research Centre, Islamabad in the experimental vegetable field during 1983 . Heads of the affected cabbage plants were covered with white mycelial growth associated with large black sclerotia of different size $(2-10 \mathrm{~mm})$. On the basis of cultural and sclerotial characteristics, the causal organism was identified as Sclerotinia sclerotiorum and its pathogenicity was also determined by fulfilling Koch's postulates.

Additional key words : Brassica oleracea var. capitata, head rot, Sclerotinia, identification, pathogenicity, Pakistan.

Une pourriture à Sclerotinia a été observée sur chou, en 1983, au NARC d'Islamabad dans les parcelles expérimentales de plantes potagères. La " pomme " des choux attaqués est couverte d'un mycélium blanc associé à de gros sclérotes noirs $(2-10 \mathrm{~mm})$. L'organisme en cause a été identifié à Sclerotinia sclerotiorum d'après l'aspect des sclérotes et les caractéristiques culturales. Son pouvoir pathogène a été confirmé par vérification des règles de Koch.

Mots clés additionnels : Brassica oleracea var. capitata, Sclerotinia, identification, pouvoir pathogène, Pakistan.

\section{INTRODUCTION}

Sclerotinia sclerotiorum (Lib.) de Bary is a soilborne plant pathogen with wide host range, worldwide importance, and ability to survive in the soil for long periods as sclerotia (PURDY, 1979; WILLETTS \& WONG, 1980). Dillard \& HUNTER (1986) reported that Sclerotinia cabbage rot caused by $S$. sclerotionum was usually serious in the central and western region of New York State in 1984. HiNE \& WHEELER (1970) also reported the occurrence of cabbage rot in Arizona (USA). WALKER (1952) reported that the vegetable cabbage crop is usually affected in the field after midseason and the fungus advances up to main stem from soil causing a soft cortical rot that eventually advances into the cabbage head. The disease can cause serious losses in the field, in storage and under market conditions (RAMSEY, 1925 ; RAMSEY et al., 1938).

Sclerotinia rot disease incited by $S$. sclerotiorum was observed on cabbage (Brassica oleracea var. capitata
L.) in the experimental vegetable plots during MarchApril 1983 at National Agricultural Research Centre, Islamabad. Disease incidence up to $10 \%$ was recorded. In severely diseased plants the pathogen caused a soft rotting of stem and heads. Diseased heads were covered with white mycelial growth having white grey and large black sclerotia, $2-10 \mathrm{~mm}$ in size depending upon the maturity stage after abundant precipitation (fig. 1). Similar disease symptoms has already been described by WALKER (1952).

In Pakistan, the causal organism has already been reported on oilseed Brassica spp. (MIRZA \& YASMIN, 1984a), on esg plant (ILYAS \& BAJWA, 1984), on flax (MIRZA \& ILYAS, 1984), on pea (ILYAS, 1984) and on sunflower (MIRZA \& YASMIN, 1984b), but cabbage appears to be a new host of $S$. sclerotiorum as it is not included in the Fungi of Pakistan (AHMAD, 1956, 1969 ; MIRZA \& QURESHI, 1978) and in the list of Diseases of Economic Plants (GHAFOOR \& KHAN, 1976). 


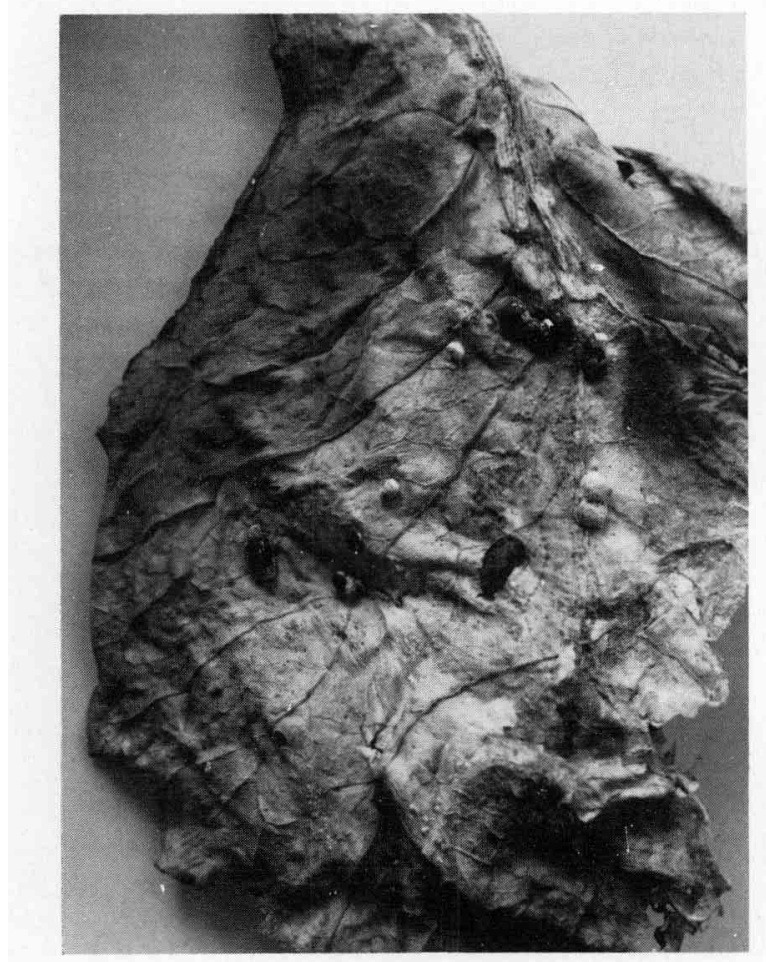

Figure 1

Cabbage rot caused by $\mathrm{S}$. sclertiorium with white mycelium associated with sclerotia.

Sclérotes et mycélium blanc de S. sclerotiorum sur feuille de chou.

The objectives of this paper were to report the first occurrence of $S$. sclerotiorum on cabbage and to establish the identity of the pathogen.

\section{MATERIALS AND METHODS}

\section{A. Isolations}

During surveys of the experimental vegetable plots at NARC, Islamabad in 1983, affected heads of cabbage carrying sclerotia were collected for isolation. Sclerotia and $3 \mathrm{~mm}$ pieces of affected heads were disinfected in $1.0 \%$ solution of sodium hypochlorite for $2-3 \mathrm{~min}$, rinsed throughly in sterile distilled water (SDW), dried on sterile filter paper and plated on $9 \mathrm{~cm}$ diameter Petri dishes containing $15 \mathrm{ml}$ of potato dextrose agar (PDA) medium, amended with $100 \mu \mathrm{g} / \mathrm{ml}$ streptomycin sulphate, then incubated at $23{ }^{\circ} \mathrm{C}$ for 7-10 days. Thus the causal organism was isolated in pure culture.

\section{B. Pathogenicity}

Pathogenicity of the causal organism was established on cabbage heads under controlled conditions. Seven- day old mycelial cultures prepared from a single sclerotium of the causal organism on PDA at $23{ }^{\circ} \mathrm{C}$ were used for inoculations. The heads were wounded with a sterile cork borer and a $3 \mathrm{~mm}$ PDA dises from 5 to 7 day old cultures were placed on the wounded portion. The wounds were sealed with vaseline to prevent drying of the culture and the wounds. Inoculated heads with simple sterile PDA were used as control. Head inoculations were replicated five times with 5 heads per replicate. Inoculated heads, along with controls, were placed in a controlled environmental chamber where relative humidity near $100 \%$ was maintained by water mist and temperatures were maintained at $25( \pm 2:){ }^{\circ} \mathrm{C}$, and examined for disease symptoms development.

\section{RESULTS AND DISCUSSION}

\section{A. Isolation and identification}

A pure culture of white mycelial growth developed. Hyphae were hyaline, much branched and septate. Large sclerotia of variable size and shape $(2-6 \mathrm{~mm})$ formed generally in concentric rings or single ring near the outer edge of Petri plates within 5-7 days after incubation at $23{ }^{\circ} \mathrm{C}$. The causal organism isolated was identified as Sclerotinia sclerotiorum (Lib.) de Bary, as described by PURDY (1955).

\section{B. Pathogenicity}

The disease was reproduced successfully when cabbage heads of a local susceptible variety were artificially inoculated with the culture of suspect pathogen. Inoculated heads in all the 5 replications first developed symptoms of soft watery rot lesions on the heads which later on covered by white cottony mycelial growth within 7-10 days after inoculations. Severely infected heads became soft watery rotted as the disease progressed and large black sclerotia formed on the diseased tissue after 20-25 days. The causal organism was successfully reisolated from all the artificial inoculated heads and yielded a fungus which was similar to the original culture of S. sclerotiorum and thus confirmed its pathogenicity. In control no disease symptoms were observed and no organism was recovered from them.

The test demonstrated that cabbage rot was caused by $S$. sclerotiorum and cabbage appears to be a new host of this pathogen in Pakistan.

Reçu le 3 juillet 1987. Accepté le 4 octobre 1987. 


\section{REFERENCES}

Ahmad S., 1956. Fungi of Pakistan. Biol. Soc, Pak. Lahore, Mon. I, 1-126.

Ahmad S., 1969. Fungi of Pakistan. Biol. Soc. Pak. Lahore, Mon. 5, 110.

Dillard H. R., Hunter J. E., 1986. Association of common rageweed with Sclerotinia rot of cabbage in the New York State. Plant Dis., 70, 26-28.

Ghafoor A., Khan S. A. J., 1976. List of diseases of economic plants in Pakistan, 82 p.

Hine R. B., Wheeler J. P., 1970. The occurrence of some previously unreported diseases in Arizona. Plant Dis. Rep., 54, 179-180.

Ilyas M. B., 1984. A new record of post harvest decay of pea by Sclerotinia sclerotiorum. Pak. J. Agric. Sci., 21 (1-2), 107-108.

Ilyas M. B., Bajwa M. N., 1984. Sclerotinia wilt of egg plant. Pak. J. Agric. Sci., 12 (3-4), 248-249.

Mirza M. S., Ilyas M. B.. 1984. Sclerotinia stem rot of flax in Pakistan. Pak. J. Agric. Sci., 21 (3-4), 246-247.

Mirza J. H., Qureshi M. S. A., 1978. Fungi of Pakistan. Dept. of Plant Pathol. Univ. of Agric. Faisalabad, 311 p.
Mirza M. S., Yasmin A., 1984a. Studies on Sclerotinia stem blight of oilseed crops. Nat. Conf. Plant Scientists No. 106, 53 P. (Abstr.).

Mirza M. S., Yasmin A., 1984b. Sclerotinia stalk and head rot of sunflower. F.A.O. Plant Prot, bull., 32 (4), 147.

Purdy C. H., 1955. A broader concept of the species of Sclerotinia sclerotiorum based on variability. Phytopathology, 45, 421-427.

Purdy L. H., 1979. Sclerotinia sclerotiorum : history, diseases and symptomology, host range, geographic distribution and impact. Phytopathology, 69, 875-880.

Ramsey G. B., 1925. Sclerotinia species causing decay of vegetables under transit and market conditions. J. Agric. Res., 31, 597-632.

Ramsey G. B., Wiant J. S., Link G. K. K., 1938. Market diseases of fruits and vegetables : crucifers and cucurbitas. U.S. Dept. Agric., Misc. Pub. 292.

Walker J. C., 1952. Diseases of vegetables crops. Mc Graw Hill, New York, 529 p.

Willetts H. J., Wong J. A. L., 1980. The biology of Sclerotinia sclerotiorum, $S$. trifoliorum and $S$. minor with emphasis on specific nomenclature. Bot. Rev., 46, 101-165. 